\title{
The Effect between Product Quality and Promotional Activities on Consumer Purchase Interest (A Case Study of Garuda Peanut Products Produced by PT. Garudafood, Tbk)
}

\section{Udin Ahidin}

Universitas Pamulang, Banten, Indonesia

lecturer00406@unpam.ac.id

\begin{abstract}
This study aims to determine the effect of product quality and promotional activities on consumer buying interest (Case Study of Garuda Peanut Products Produced by PT. Garudafood, Tbk). The method used is explanatory research with analysis techniques using statistical analysis with regression testing, correlation, determination and hypothesis testing. The results of this study, product quality has a significant effect on purchase intention by $45.2 \%$, hypothesis testing obtained $t$ count $>t$ table or (8.990> 1.984). Promotional activities have a significant effect on purchase intention by $37.1 \%$, hypothesis testing is obtained t count $>t$ table or (7.599> 1.984). Product quality and promotional activities simultaneously have a significant effect on buying interest with the regression equation $Y=10.422+0.434 X 1+0.312 X 2$ and the contribution of the effect is $52.2 \%$, the hypothesis test obtained $F$ count $>F$ table or (53.010>2,700).
\end{abstract}

Keywords

product quality, promotion activities, purchase interest

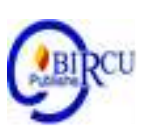

\section{Introduction}

The development and progress of industry, one of which we can see with the increasingly rapid development of the business world. This can be seen with the emergence of the goods and services industry. The rapid progress of the industrial sector has created a level of intense business competition.

Increasing the standard of life and lifestyle of the people who are very diverse today, making companies must be able to create creative and innovative products and keep up with current fashion developments, in addition, of course, companies must carry out promotional activities to introduce and market these products.

In an effort to determine forward steps to suit the company's goals, namely to obtain the maximum possible profit with maximum potential and capabilities, one thing that must be done to achieve these goals is to carry out marketing activities. Marketing is one of the areas that must be considered for the success of the company in addition to other activities such as production, personnel and finance (budgeting).

In the field of marketing various problems arise apart from competition as well as the development of product diversity, increasing tastes consumers, and the existence of new products that are produced. Therefore, companies are required to be able to face and solve various existing problems. In dealing with problems that come from various directions the company must be able to increase the effectiveness of the entire company management in handling product marketing. Conditions like this are what ultimately causes business actors to be more incessant in trying to find solutions and business programs that can increase the competitiveness of companies in their business. 
However, even though the company has tried to compete and provide the best for consumers, it is not certain that it will be able to guarantee the success of its efforts to achieve company goals, because each consumer has different tastes and desires. Therefore, every company has a different marketing strategy, which is the best strategy in every company. By doing this the company can attract interest, interest, and inspire people to buy goods or services produced by the company. PT. Garudafood, Tbk is a private company engaged in the food business by prioritizing the best quality for its products. Various types of food products are produced by the company. One of them is the Peanut product, which is a snack product.

The problems that occurred at PT. Garudafood, Tbk, namely the ineffective promotional activities carried out by PT. Garudafood, Tbk, Consumer purchase interest for mayasi bean products is still low and promotional activities still have no impact on consumer buying interest.

For this reason, it is hoped that the promotional activities carried out can hit the target precisely, in order to provide information about mayasi bean products. Promotions are intended to attract customers' buying interest, among others by providing complete information to customers about a product being marketed, if promotional activities are carried out properly, customers will be interested and will buy the product.

Therefore, promotion plays an important role in achieving company goals, especially in getting maximum profit with the smallest cost. Promotion is the main activity carried out by entrepreneurs for the survival of the company which then develops and achieves the desired sales results, so that it can be interpreted that customer satisfaction is a condition in which the wishes and expectations of customers can be met.

Promotional activities are carried out in order to provide information to consumers who still do not know the product clearly, supported by the presentation of other promotional programs related to the product being marketed, this can encourage consumer buying interest in a product, consumer buying interest is expected to change from that. Previously not interested in buying becomes interested in buying. Brand image is the whole of consumers' perceptions of the brand or how they perceive it, which may not be similar to brand identity (Hossain, 2007). Companies must work towards the consumer experience to ensure that everything customers see and hear is really all they want. The image of the brand is related to attitudes in the form of beliefs and preferences for a brand. Sutisna (2003) states that consumers with a positive image of a particular brand are more likely to make purchases.

Slameto (2010: 180) states that "Interest is a feeling of preference and interest in something or activity, without being asked." Contradictory things actually happen in the company, including promotional activities conducted by PT. Garudafood, Tbk in influencing consumer buying interest is still very minimal, consumers' buying interest tends to decrease, thereby reducing sales turnover.

Marketing strategy is a plan that outlines the company's expectations of the impact of various marketing activities or programs on the demand for products or product lines in certain target markets". According to Andrews in Alma's book (2009: 199) that: "Marketing strategy is a pattern of decisions in companie that determine and express goals, intentions or goals that produce the main policy and plan for the achievement of objectives and detail the range of business that will be pursued by the company. (Dianto et al, 2020).

This is influenced by the activities carried out, for example organizing product socialization programs as a means of providing information about existing old products with the aim that the benefits of the products can be used properly by customers, in addition to attracting customers' buying interest in PT. Garudafood, Tbk also organizes events to introduce its new products, this method is intended to provide an overview of consumers about the product, and to attract more consumers' attention, the implementation is 
recommended to provide various kinds of gifts that can attract consumer buying interest, thus the authors are interested in conducted further research, while the title of the research that the author did was "The Effect of Product Quality and Promotion Activities on Consumer Purchase Intention. Study of Garuda Peanut Products Produced by PT Garudafood"

\section{Review of Literatures}

\subsection{Product Quality}

Products are not only in the form of real goods but can be in the form of services, so products can provide different satisfaction so that companies are required to be more creative and have a broad view of the products produced.

According to Kotler and Armstrong (2017: 299) argue "Product quality is the ability of a product to perform its function, this includes the useful life of the product, reliability, ease, use and repair, and other values. The quality of the product can be viewed from two points of view, namely an internal point of view and an external point of view. From the marketing point of view, quality is measured by the perception of the buyer, so the point of view used to see the quality of the product is an external point of view.

The development of business organizations depends on the quality of the products they produce. The better the product produced and useful, the more consumers will enjoy it, especially to meet their daily needs. The quality of products that are in great demand by consumers can be seen from several factors including packaging, price, quality, and benefits obtained by consumers. (Romdonny et al, 2019)

\subsection{Promotional Activities}

Promotion is a series of activities to communicate, provide knowledge and convince people about a product so that they recognize the greatness of the product, as well as bind their thoughts and feelings in a form of loyalty to the product. According to Kotler and Keller (2017: 263) argue "Promotion is a special ingredient of personal advertising, sales promotion and public relations that companies use to achieve their advertising and marketing goals".

Promotion strategy is a concept that is close to communication science. In the promotion, there are various forms of communication learned in communication science such as advertising, publicity, communication from mouth to mouth, personal sales, and direct marketing. (Amin, 2019)

\subsection{Buying Interests}

Purchase interest is consumer behavior that shows the extent of commitment to make a purchase. The needs and desires of consumers for goods and services develop from time to time and influence their behavior in purchasing products. Consumer behavior in making buying decisions considers what goods and services to buy, where, when, how, in what quantity, and why to buy the product. According to Ferdinand (2016: 132), Purchase interest is a mental statement from the consumer that reflects the purchase plan for a number of products with a certain brand. 


\section{Research Methods}

The population in this study amounted to 100 respondents PT. Garudafood, Tbk. The sample in this study amounted to 100 respondents. The type of research used is associative, where the aim is to determine the effect of the independent variable on the dependent variable either partially or simultaneously.In analyzing the data used instrument test, classical assumption test, regression, coefficient of determination and hypothesis testing.

\section{Result and Discussion}

\subsection{Result}

\section{a. Descriptive Analysis}

In this test, it is used to determine the minimum and maximum score, the mean score and the standard deviation of each variable. The results are as follows:

Table 1. Descriptive Statistics Analysis Results

\begin{tabular}{|l|r|r|r|r|r|} 
& N & Minimum & Maximum & Mean & Std. Deviation \\
\hline Product quality (X1) & 100 & 32 & 48 & 38.56 & 3.862 \\
\hline $\begin{array}{l}\text { Promotional activities } \\
\text { (X2) }\end{array}$ & 100 & 30 & 46 & 38.37 & 3.659 \\
\hline Purchase interest (Y) & 100 & 32 & 46 & 39.14 & 3.490 \\
\hline Valid N (listwise) & 100 & & & & \\
\hline
\end{tabular}

The product quality obtained a minimum variance of 32 and a maximum variance of 48 with a mean score of 38.56 with a standard deviation of 3.862. Promotional activities obtained a minimum variance of 30 and a maximum variance of 46 with a mean score of 38.37 with a standard deviation of 3.659. Purchase interest obtained by a minimum variance of 32 and a maximum variance of 46 with a mean score of 39.14 with a standard deviation of 3,490 .

\section{b. Verification Analysis}

This analysis aims to determine the effect of the independent variable on the dependent variable. The test results are as follows:

\section{Multiple Linear Regression Analysis}

This regression test is intended to determine changes in the dependent variable if the independent variable changes. The test results are as follows:

Table 2. Multiple Linear Regression Test Results

\section{Coefficients $^{\mathrm{a}}$}

Unstandardized Standardized

Coefficients Coefficients

\begin{tabular}{l|r|r|r|r|r} 
Model & \multicolumn{1}{c}{ B } & Std. Error & \multicolumn{1}{c|}{ Beta } & \multicolumn{1}{c}{$\mathrm{t}$} & \multicolumn{1}{c}{ Sig. } \\
\hline 1 (Constant) & 10.422 & 2.829 & & 3.684 & .000 \\
\hline $\begin{array}{l}\text { Product quality (X1) } \\
\begin{array}{l}\text { Promotional } \\
\text { activities (X2) }\end{array}\end{array}$ & .434 & .078 & .480 & 5.545 & .000 \\
\hline
\end{tabular}

a. Dependent Variable: Purchase interest (Y) 
Based on the test results in the table above, the regression equation $\mathrm{Y}=10.422+$ $0.434 \mathrm{X} 1+0.312 \mathrm{X} 2$ is obtained. From this equation it is explained as follows:

1) A constant of 10,422 means that if product quality and promotional activities are not available, there is already a purchase interest value of 10,422 points.

2) The product quality regression coefficient is 0.434 , this number is positive, meaning that every time there is an increase in product quality of 0.434 , the purchase interest will also increase by 0.434 points.

3) The regression coefficient for promotional activities is 0.312 , this number is positive, meaning that every increase in promotional activities is 0.312 , the purchase interest will also increase by 0.312 points.

\section{Correlation Coefficient Analysis}

Correlation coefficient analysis is intended to determine the level of strength of the relationship between the independent variable and the dependent variable either partially or simultaneously. The test results are as follows:

Table 3. Test Results of Correlation Coefficient of Product Quality to Purchase Intention Correlations $^{\text {b }}$

\begin{tabular}{|c|c|c|c|}
\hline & & $\begin{array}{l}\text { Product quality } \\
\text { (X1) }\end{array}$ & $\begin{array}{c}\text { Purchase } \\
\text { interest (Y) }\end{array}$ \\
\hline \multirow[t]{2}{*}{ Product quality (X1) } & $\begin{array}{l}\text { Pearson } \\
\text { Correlation }\end{array}$ & 1 & $.672^{* * *}$ \\
\hline & Sig. (2-tailed) & & .000 \\
\hline \multirow[t]{2}{*}{ Purchase interest (Y) } & $\begin{array}{l}\text { Pearson } \\
\text { Correlation }\end{array}$ & $.672^{* *}$ & 1 \\
\hline & Sig. (2-tailed) & .000 & \\
\hline
\end{tabular}

Based on the test results obtained a correlation value of 0.672 , meaning that product quality has a strong relationship with purchase intention.

Table 4. Correlation Coefficient Testing Results of Promotional Activities against Purchase Intention

Correlations $^{\mathrm{b}}$

\begin{tabular}{llr|r} 
& & & \multicolumn{2}{c}{$\begin{array}{c}\text { Purchase } \\
\text { interest (Y) }\end{array}$} \\
\hline $\begin{array}{l}\text { Promotional } \\
\text { activities (X2) }\end{array}$ & Pearson & 1 & $.609^{* *}$ \\
& Correlation & & .000 \\
\cline { 2 - 3 } $\begin{array}{l}\text { Sig. (2-tailed) } \\
\text { Purchase interest }\end{array}$ & $\begin{array}{l}\text { Pearson } \\
\text { Correlation }\end{array}$ & $.609^{* *}$ & 1 \\
\cline { 2 - 3 } & Sig. (2-tailed) & .000 & \\
\hline
\end{tabular}

Based on the test results obtained a correlation value of 0.609 , meaning that promotional activities have a strong relationship with purchase intention. 
Table 5. Correlation Coefficient Testing Results of product quality and promotional activities simultaneously on purchase intention

\section{Model Summary}

\begin{tabular}{|c|c|c|c|c|}
\hline Model & $\mathrm{R}$ & R Square & $\begin{array}{l}\text { Adjusted R } \\
\text { Square }\end{array}$ & $\begin{array}{l}\text { Std. Error of the } \\
\text { Estimate }\end{array}$ \\
\hline 1 & $.723^{\mathrm{a}}$ & .522 & .512 & 2.437 \\
\hline
\end{tabular}

Based on the test results obtained a correlation value of 0.723 means that product quality and promotional activities simultaneously have a strong relationship with purchase intention.

\section{Analysis of the coefficient of determination}

Analysis of the coefficient of determination is intended to determine the percentage of influence of the independent variable on the dependent variable either partially or simultaneously. The test results are as follows:

Table 6. Test Results for the Determination of Product Quality Coefficient of Purchase Intention

\section{Model Summary}

\begin{tabular}{lr|r|r|r} 
Model & R & R Square & $\begin{array}{c}\text { Adjusted R } \\
\text { Square }\end{array}$ & $\begin{array}{c}\text { Std. Error of the } \\
\text { Estimate }\end{array}$ \\
\hline 1 & $.672^{\mathrm{a}}$ & .452 & .446 & 2.597 \\
\hline
\end{tabular}

a. Predictors: (Constant), Product quality (X1)

Based on the test results, it was found that the value of determination was 0.452 , meaning that the product quality had a $45.2 \%$ contribution to the purchase intention.

Table 7. Results of Testing the Coefficient of Determination of Promotional Activities on Purchase Intention

\section{Model Summary}

\begin{tabular}{|c|c|c|c|c|}
\hline \multicolumn{5}{|c|}{ Model Summary } \\
\hline Model & $\mathrm{R}$ & R Square & $\begin{array}{l}\text { Adjusted R } \\
\text { Square }\end{array}$ & $\begin{array}{l}\text { Std. Error of the } \\
\text { Estimate }\end{array}$ \\
\hline 1 & $.609^{a}$ & .371 & .364 & 2.783 \\
\hline
\end{tabular}

a. Predictors: (Constant), Promotional activities (X2)

Based on the test results obtained a determination value of 0.371 means that promotional activities have an influence contribution of $37.1 \%$ on purchase intention.

Table 8. Results of Testing the Coefficient of Determination of Product Quality and Promotional Activities on Purchase Intention

Model Summary

\begin{tabular}{|c|c|c|c|c|}
\hline \multicolumn{5}{|c|}{ Model Summary } \\
\hline Model & $\mathrm{R}$ & R Square & $\begin{array}{l}\text { Adjusted R } \\
\text { Square }\end{array}$ & $\begin{array}{l}\text { Std. Error of the } \\
\text { Estimate }\end{array}$ \\
\hline 1 & $.723^{\mathrm{a}}$ & .522 & .512 & 2.437 \\
\hline
\end{tabular}




\section{Hypothesis Testing}

a). Partial hypothesis test ( $t$ test)

Hypothesis testing with the $\mathrm{t}$ test is used to determine which partial hypothesis is accepted. The first hypothesis: There is a significant influence between product qualities on purchase intention.

Table 9. Hypothesis Test Results on Product Quality against Purchase Intention

\begin{tabular}{|c|c|c|c|c|c|}
\hline \multirow[b]{3}{*}{ Model } & \multicolumn{3}{|c|}{ Coefficients $^{\mathbf{a}}$} & \multirow[b]{3}{*}{$\mathrm{t}$} & \multirow[b]{3}{*}{ Sig. } \\
\hline & \multicolumn{2}{|c|}{$\begin{array}{l}\text { Unstandardized } \\
\text { Coefficients }\end{array}$} & \multirow{2}{*}{$\begin{array}{c}\text { Standardized } \\
\text { Coefficients } \\
\text { Beta } \\
\end{array}$} & & \\
\hline & $\mathrm{B}$ & Std. Error & & & \\
\hline 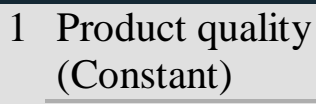 & 15.712 & 2.619 & & 6.000 & .000 \\
\hline (X1) & .608 & .068 & .672 & 8.990 & .000 \\
\hline
\end{tabular}

a. Dependent Variable: Purchase interest (Y)

Based on the test results in the table above, the value of $t$ count $>t$ table or (8.990> 1.984) is obtained, thus the first hypothesis is that there is a significant influence between product quality on purchase intention is accepted.

Table 10. Hypothesis Test Results of Promotional Activities against Purchase Intention.

\section{Coefficients $^{\mathrm{a}}$}

\begin{tabular}{|c|c|c|c|c|c|}
\hline \multirow[b]{2}{*}{ Model } & \multicolumn{2}{|c|}{$\begin{array}{l}\text { Unstandardized } \\
\text { Coefficients }\end{array}$} & \multirow{2}{*}{$\begin{array}{c}\text { Standardized } \\
\text { Coefficients } \\
\text { Beta }\end{array}$} & \multirow[b]{2}{*}{$\mathrm{t}$} & \multirow[b]{2}{*}{ Sig. } \\
\hline & $\mathrm{B}$ & Std. Error & & & \\
\hline 1 (Constant) & 16.852 & 2.946 & & 5.720 & .000 \\
\hline $\begin{array}{l}\text { Promotional } \\
\text { activities (X2) }\end{array}$ & .581 & .076 & .609 & 7.599 & .000 \\
\hline
\end{tabular}

a. Dependent Variable: Purchase interest (Y)

Based on the test results in the table above, the value of $t$ count $>t$ table or (7.599> 1.984) is obtained, thus the second hypothesis proposed that there is a significant effect between promotional activities on purchase interest is accepted.

b). Simultaneous Hypothesis Test (Test F)

Hypothesis testing with the F test is used to determine which simultaneous hypothesis is accepted. The third hypothesis there is a significant influence between product quality and promotional activities on purchase intention.

Table 11. Hypothesis Test Results Quality of products and promotional activities on purchase intention

\section{ANOVA $^{\mathrm{a}}$}

\begin{tabular}{|c|c|c|c|c|c|c|}
\hline \multicolumn{2}{|c|}{ Model } & $\begin{array}{c}\text { Sum of } \\
\text { Squares }\end{array}$ & $\mathrm{df}$ & $\begin{array}{l}\text { Mean } \\
\text { Square }\end{array}$ & $\mathrm{F}$ & Sig. \\
\hline \multirow[t]{3}{*}{1} & Regression & 629.813 & 2 & 314.906 & 53.010 & $.000^{\mathrm{b}}$ \\
\hline & Residual & 576.227 & 97 & 5.940 & & \\
\hline & Total & 1206.040 & 99 & & & \\
\hline
\end{tabular}


Based on the test results in the table above, the calculated $F$ value> $F$ table or $(53,010>2,700)$ is obtained, thus the third hypothesis that is proposed that there is a significant effect between product quality and promotional activities on purchase intention is accepted.

\subsection{Discussion}

\section{a. The Effect of Product Quality on Purchase Intention}

Product quality has a significant effect on purchase intention with a correlation of 0.672 or has a strong relationship with an influence contribution of $45.2 \%$. Hypothesis testing obtained $t$ value $>t$ table or $(8.990>1.984)$. Thus, the first hypothesis proposed that there is a significant effect between product quality and purchase intention is accepted.

\section{b. The Influence of Promotional Activities on Purchase Intention}

Promotional activities have a significant effect on purchase intention with a correlation of 0.609 or have a strong relationship with an influence contribution of $37.1 \%$. Hypothesis testing obtained $t$ value $>t$ table or $(7.599>1.984)$. Thus, the second hypothesis proposed that there is a significant effect between promotional activities and purchase intention is accepted.

\section{c. The Influence of Product Quality and Promotional Activities on Purchase Intention}

Product quality and promotional activities have a significant effect on purchase intention by obtaining the regression equation $\mathrm{Y}=10.422+0.434 \mathrm{X} 1+0.312 \mathrm{X} 2$, the correlation value is 0.723 or has a strong relationship with the contribution of influence of $52.2 \%$ while the remaining $47.8 \%$ is influenced by factors other. Hypothesis testing obtained the value of $F$ count $>F$ table or $(53,010>2,700)$. Thus, the third hypothesis proposed that there is a significant effect between product quality and promotional activities on purchase intention is accepted.

\section{Conclussion}

a. Product quality has a significant effect on purchase intention with a contribution of influence of $45.2 \%$. Hypothesis test obtained t value>t table or (8.990>1.984).

b. Promotional activities have a significant effect on purchase intention with an influence contribution of $37.1 \%$. Hypothesis test obtained $t$ value> $t$ table or (7.599>1.984).

c. Product quality and promotional activities have a significant effect on purchase intention with an influence contribution of $52.2 \%$ while the remaining $47.8 \%$ is influenced by other factors. Hypothesis test obtained the value of $F$ count $>F$ table or $(53,010>2,700)$.

\section{Suggestions}

a. The company is able to make products with many variants but still prioritizes and maintains the quality of its production in order to meet consumer expectations

b. Companies must be able to optimize various media in supporting sales with effective promotion

c. Consumer purchasing interest that must be maintained by providing optimal service both before purchase and post purchase 


\section{References}

Amin,M. et al. (2019). Marketing Communication Strategy To Improve Tourism Potential. Budapest International Research and Critics Institute-Journal (BIRCI-Journal). P. 160166.

Basu Swasta dan Hani Handoko. (2010). Manajemen Pemasaran: Analisa dan Perilaku Konsumen. BPFE. Yogyakarta

Bilson,Simamora. (2011). Memenangkan Pasar dengan Pemasaran Efektif dan Profitabel. Jakarta: PT. Gramedia Pustaka Utama

Darmadi Durianto. (2010). Manajemen Pemasaran, Andi Offset, Yogyakarta.

Daryanto, 2011, Sari Kuliah Manajemen Pemasaran, Bandung: PT Sarana Tutorial Nurani Sejahtera.

Dianto, E. et al. (2020). BNI Marketing Strategy for Credit Cards in Dealing Global Competition in State Bank Indonesia (Persero) Tbk Banda Aceh Branch Office. Budapest International Research and Critics Institute-Journal (BIRCI-Journal). P. 11341146

Effendy, A. A., \& Sunarsi, D. (2020). Persepsi Mahasiswa Terhadap Kemampuan Dalam Mendirikan UMKM Dan Efektivitas Promosi Melalui Online Di Kota Tangerang Selatan. Jurnal Ilmiah MEA (Manajemen, Ekonomi, \& Akuntansi), 4(3), 702-714.

Engkos Ahmad Kuncoro, Adithya wiranegara (2010). Pengaruh promosi dan atribut produk terhadap keputusan pembelian pada produk telkom speedy. Jurnal Manajemen

H Wijoyo, D Sunarsi. (2020). Manajemen internasional. CV. Insan Cendekia Mandiri 1, 1175

Hermwan Agus. (2012). Komunikasi Pemasaran.Jakarta, Erlangga

Istijanto, (2009). Aplikasi Praktis Riset Pemasaran, Gramedia Pustaka Utama : Jakarta

Jasmani, J., Sutiman, S., \& Sunarsi, D. (2020). Analysis of the Effect of Prices, Promotions and Products on Purchase Interest Impacts on Consumer Satisfaction of VIVO Brand Mobile Phones in South Tangerang Region. Jurnal Ad'ministrare, 7(1), 73-82.

Jasmani, Jasmani, and Denok Sunarsi. "The Influence of Product Mix, Promotion Mix and Brand Image on Consumer Purchasing Decisions of Sari Roti Products in South Tangerang." PINISI Discretion Review 1.1 (2020): 165-174.

Kotler Philip , dan Gary Amstrong. (2012). Principles Of Marketing, Global Edition, 14 Edition, Pearson Education.

Kotler, Philip and Kevin Lane Keller. (2011). Manajemen Pemasaran, Edisi 13 Jilid 1 dan 2, Alih Bahasa : Bob Sabran, Erlangga, Jakarta.

Kotler, Philip and kevin lane keller. (2012). Marketing management 13. New jersey: Pearson Prentice hall, Inc.

Kotler, Philip dan Gary Armstrong. (2009). Prinsip-Prinsip Pemasaran, Edisi 12, jilid 2, Jakarta: Erlangga.

Kotler, Philip dan Gary Armstrong.(2010). Principles of Marketing (Edisi 13). United States of America: Pearson

Machfoedz, Mahmud. (2010). Komunikasi Pemasaran Modern. Yogyakarta : Cakra Ilmu. Moriarty, Sandra, et al. (2011). Advertising. Kencana : Jakarta.

Philip Kotler (2017) Manajemen Pemasaran, Edisi Keempat Belas, Jakarta: PT. Indeks.

Pranoto, P., Jasmani, J., \& Marayasa, I. N. (2019). Pelatihan Digital Marketing Untuk Peningkatan Perekonomian Anggota Karang Taruna Al Barkah Di Kampung CicayurTangerang. Jurnal Pengabdian Dharma Laksana, 1(2), 250-258. 
Rao, Purba, (2012). "Measuring Consumer Perceptions Through Factor Analysis", The Asian.

Riduwan, Akdon. (2011). Rumus dan Data dalam Aplikasi Statistika. Bandung : Alfabeta

Romdonny, J. et al. (2019). Factors Affecting Customer Loyalty in Products. Budapest International Research and Critics Institute-Journal (BIRCI-Journal). p. 337-343

Santoso, Singgih (2015). "Menguasai Statistik Multivariat". Jakarta: PT Elex Media Komputindo.

Slameto. (2010). Belajar dan factor-faktor yang mempengaruhinya. PT. Rineka cipta : Jakarta.

Subagyo, Ahmad . (2010). Marketing In Business. edisi pertama, cetakan pertama Jakarta: Mitra Wacana Media

Sugiono. (2011). Metode Penelitian Pendidikan (Pendekatan Kuantitatif, Kualitatif, dan R\&D); Alfabeta. Bandung

Sugiyono. (2017). "Metode Penelitian Administrasi : dilengkapi dengan Metode R \& D". Bandung: Alfabeta.

Sugiyono. (2009). Metode Penelitian Bisnis (Pendekatan Kuantitatif, Kualitatif, dan R\&D). Bandung: Alfabeta.

Sugiyono. (2010). Statistika untuk Penelitian. Cetakan ke-16, CV. Alfabeta, Bandung.

Suhartanto (2014). "Metode Riset Pemasaran". Bandung: Alfabeta

Sunarsi, D. (2020). Pengaruh Bauran Pemasaran Dan Kualitas Pelayanan Terhadap Kepuasan Konsumen Pada Giant Dept Store Cabang BSD Tangerang. E-Mabis: Jurnal Ekonomi Manajemen dan Bisnis, 21(1).

Supangat, Andi. (2008). Statistika Dalam Kajian Deskriptif, Inferensi dan Parametrik. Jakarta: Kencana Prenada

Tjiptono, Fandy. (2011). Strategi Pemasaran, Edisi 3, Andi: Yogyakarta

Wijoyo, H. (2020). Analisis Pengendalian Internal Dalam Pemberian Kredit Pada PT Bank Perkreditan Rakyat (BPR) Indomitra Mandiri. TIN: Terapan Informatika Nusantara, 1(4), 157-162.

Wijoyo, H., Handoko, A. L., Santamoko, R., \& Sunarsi, D. (2020). Strategy Model For Character Education Through Digital Media For Courses And Training Participants. EProsiding Pascasarjana Universitas Negeri Gorontalo, 1-8. 